\title{
Genetic and epigenetic changes of GPX1 and GPX3 in human clear-cell renal cell carcinoma
}

\author{
E. E. Rudenko ${ }^{1}$, G. V. Gerashchenko ${ }^{1}$, Y. V. Lapska ${ }^{1}$, O. O. Bogatyrova ${ }^{1}$, \\ S. O. Vozianov' ${ }^{2}$ Y. M. Zgonnyk², V. I. Kashuba ${ }^{1}$ \\ ${ }^{1}$ Institute of Molecular Biology and Genetics, NAS of Ukraine \\ 150, Akademika Zabolotnoho Str., Kyiv, Ukraine, 03680 \\ ${ }^{2}$ Institute of Urology, NAMS of Ukraine \\ 9A, Kotsubinsky Str., Kyiv, Ukraine, 04053 \\ rudenko.jene@ukr.net
}

\begin{abstract}
Aim. To find putative diagnostic and prognostic markers of cancerogenesis. Methods. Analysis of microarray and SAGE data, quantitative PCR (Q-PCR), bisulfite sequencing, methylation-specific PCR. Results. Bioinformatic analysis of microarray and SAGE database revealed that genes, encoding the glutathione peroxidase 1 and 3 (GPX1 and GPX3) were expressed at low levels in renal cancers. The relative gene expression of GPX1 and GPX3 that was widely inactivated in clear-cell renal cell carcinoma (ccRCC) was confirmed by Q-PCR. No correlation between expression levels and promoter methylation was found. It was found, however, that an allele with five ALA repeats in the N-terminal region of GPX1 is the most frequent polymorphic variant in ccRCC patients. Conclusions. Our data support the hypothesis that GPXI and GPX3 are involved in tumorigenesis of ccRCC and could be putative TSGs (tumor suppressor genes) in renal cancer.
\end{abstract}

Keywords: renal cell carcinoma, genetic and epigenetic regulation, chromosome 3, quantitative real time PCR, methylation status.

Introduction. Renal cancer is among the ten most common causes of cancer-related death in adults [1]. The common subtypes of renal tumors are clear-cell renal cell carcinoma (ccRCC) $(83.2 \%)$, papillary (11.3\%) and chromophobe carcinoma (4.3\%) [2]. The ccRCC is characterized by a variable and unpredictable clinical course. Patients with this disease have a poor 5-year survival [3]. Thus, accurate prediction of the course of disease is important for treatment. In spite of the large number of studies, the molecular mechanisms associated with tumor growth, metastasis, and progression of ccRCC are not sufficiently explored. One of the most important tasks is the identification of tumor suppressor genes (TSGs) [4].

One of the approaches to find a putative TSG is to analyze an open bioinformatic databases, for example,

(c) Institute of Molecular Biology and Genetics, NAS of Ukraine, 2013 oligonucleotide microarrays (microchips) database and serial analysis of gene expression (SAGE). DNA-microarray technology, based on cDNA or oligonucleotide, allows obtaining quantitative information about the expression profiles in the studied samples. On the other hand, though the microarray technology allows an analysis of expression level of thousands genes, these genes usually have been already identified. SAGE is a technology for quantitative characterization of transcriptom, i. e. the totality of mRNA in a particular type of cell or tissue $[5,6]$.

We have used different approach to perform a large-scale search for changes of gene expression in renal cancer. This may lead to identification of the genes that could be involved in renal carcinogenesis and could serve as diagnostic and prognostic tumor markers. After the search in SAGE and Microarray databases, we confirmed our findings by Q-PCR. We have also investiga- 
ted genetic and/or epigenetic changes of candidate genes in the experimental system.

Using the proposed approach, we analyzed 83 tumor samples in comparison to 84 normal tissues in 11 independent experiments.

Materials and methods. Analysis of microarray and SAGE databases. To analyze the databases « $\mathrm{R}$ Project» for Statistical Computing (www.r-project.org) was used. To process the initial microarray data available publicly the Bioconductor package was used. An additional normalization of processed data was done, using a method suited for Q-PCR. Differentially expressed genes were analyzed by limma package. The Limma gives a possibility to analyze many RNA targets simultaneously [7].

The following main steps were performed: resetting bioinformatics analysis in the context of general linear models with arbitrary units and contrasts of interest, deriving consistent, closed form estimators for the hyper parameters, using the marginal distributions of the observed statistics, reformulating the posterior odds statistic in terms of a moderated $t$-statistic in which posterior residual standard deviations are used in place of ordinary standard deviations.

SAGE map is a serial analysis of gene expression data repository supporting public use and dissemination of SAGE data. All of the SAGE libraries are present on the following website: ncbi.nlm.nih.gov/projects/SAGE/. The main idea was to compare all available libraries of normal kidney tissues with renal cancer libraries, using SAGE Digital Gene Expression Displayer (DGED) to find genes with different expression in kidney cancers.

Tissue samples. Surgically removed tumors and surrounding normal tissues were obtained from Kyiv National Urological Center (Kyiv, Ukraine). All tumor specimens were characterized according to the International System of Clinico-Morphological Classification of Tumors (TNM), based on the tumor-node-metastasis and staging classification of 1989 [8] and WHO criteria classification of 1999 [9]. The gene expression pattern was analyzed in 12 ccRCC samples and 12 corresponding normal tissues from the same patients: 6 samples were of stage 1-2 and 6 were of stage 3-4. The mean age of patients at diagnosis was $57.4 \pm 11.6$ (in the range of 36-69 years). «Normal» matched controls were obtained at the distance of minimum $2 \mathrm{~cm}$ from the tu- mor site and confirmed histologically as normal renal epithelial cells. The 13 ccRCC samples were investigated for methylation status and trinucleotide polymorphism ( 7 samples were of stage 1-2 and 6 samples were of stage 3-4). Three of these samples were studied, using bisulfite sequencing.

The present study was performed in accordance with the permission from the Ethical Committee of IMBG.

Isolation of genomic DNA and total RNA. Genomic DNA was isolated, using DNA purification Kit («Fermentas», Lithuania), according to the manufacturer's recommendations. Total RNA was isolated from all freshfrozen renal tumors and from normal tissues surrounding the tumors by homogenization with RNeasy Mini Kit («QIAGEN», USA), according to the producer's protocol. Quality of genomic DNA and total RNA was assessed by agarose gel electrophoresis; their concentration was measured, using a spectrophotometer Nano Drop ND-1000 («NanoDrop Technologies Inc.», USA). The samples, used for the Q-PCR reactions, were of high molecular weight and pure from contaminations (an OD 260/280 ranging from 1.6 to 1.8 ). From each RNA sample, $1 \mu \mathrm{g}$ of total RNA was treated with DNAseI and reversely transcribed in duplicates, as well as negative controls without enzyme, using the RevertAid ${ }^{\text {TM }} \mathrm{H}$ Minus First Strand cDNA Synthesis Kit («Thermo Scientific», SE, Sweden).

Analysis of gene expression levels. We have used QPCR to study a relative gene expression, using «BioRad» iQ5 (USA). The reactions were performed, using SYBR Green. TBP was used as a reference gene [11]. Primers for GPX1 and GPX3 were designed, using the Primer3 (http://frodo.wi.mit.edu/primer3/) and Oligo6.24 program and were synthesized by «Invitrogen» (BV, Netherlands). For mRNA detection the following primers were used:

GPXI for: 5'-CCAAGCTCATCACCTGGTCT-3'; GPX1 rev: 5'-TCGATGTCAATGGTCTGGAA-3'; $G P X 3$ for: 5'-TACGAGTACGGAGCCCTCAC-3'; GPX3 rev: 5'-CCAGAATGACCAGACCGAAT-3'; TBP for: 5'-GAACCACGGCACTGATTTTC -3'; TBP rev: 5'-CACAGCTCCCCACCATATTC-3'.

Primers for mRNA detection were selected to span for at least one big intron (more than $1 \mathrm{~kb}$ ). Each Q-PCR reaction mix contained $12.5 \mu \mathrm{l}$ of $2 \times$ YBR Green PCR Master Mix («Fermentas»), forward and reverse primers 
at optimized concentrations of $400 \mathrm{nM}, 10 \mathrm{ng} / \mu \mathrm{lDNA}$ template and a sterile water to make a final volume of $25 \mu$ l. The reaction profile was: an initial step at $72^{\circ} \mathrm{C}$ for $2 \mathrm{~min}$, denaturation at $95^{\circ} \mathrm{C}$ for $10 \mathrm{~min}$, then $35 \mathrm{cyc}$ les of denaturation at $95^{\circ} \mathrm{C}$ for $20 \mathrm{~s}$, annealing at $60^{\circ} \mathrm{C}$ for $20 \mathrm{~s}$ and extension at $72^{\circ} \mathrm{C}$ for $40 \mathrm{~s}$. To generate standard curves for the selected primers and the reference primers a $\log 10$ dilution series of cDNA was prepared at concentrations ranging from $1 \mathrm{ng}$ to $100 \mathrm{ng}$. A GPXs expression level was estimated by the $2-\Delta \Delta C P$ method of relative quantification [12].

Analysis of methylation status. Methyl-specific PCR for GPXs fragment amplification was carried out with primers specific to the methylated and unmethylated DNA sequences of GPXs CpG island. Blood gDNA treated with SssI-methyltransefrase («New England Biolabs», UK) was used as a positive control. The methylation status of genes was determined in three selected samples by bisulfite sequencing as described earlier [10]. Bisulfite treatment was performed, using the EZ DNA Methylation Kit («Zymo Research Corporation», USA). PCR was carried out for 35 cycles, comprising $30 \mathrm{~s}$ denaturation at $94^{\circ} \mathrm{C}, 30 \mathrm{~s}$ annealing at $56^{\circ} \mathrm{C}$, and $1 \mathrm{~min}$ extension at $72^{\circ} \mathrm{C}$. The cycling started by $2 \mathrm{~min}$ denaturation at $94^{\circ} \mathrm{C}$. The PCR products were purified, using the DNA Clean and Concentrator Kit («Zymo Research Corporation»), according to the manufacturer's protocol. PCR products were cloned, using the TOPO TA Cloning Kit for Sequencing («Invitrogen»). Plasmid DNA was isolated, using a Zyppy Plasmid Miniprep Kit («Zymo Research Corporation»). Sequencing was performed, using the BigDye Terminator Cycle SequencingReady Reaction kit v1.1 and ABI Prism 3100 Genetic Analyzer («Applied Biosystems», USA). The following primers were used for bisulfite sequencing of GPXs («Invitrogen»):

GPX3 BS for: 5'-GGGATTTGATTTTTATTTTT

TTGTTTAGATTTGTT-3';

GPX3 BS rev: 5'- AAAAAAAACCTTCCTCCC TTAATCATTCTA-3';

GPX1 BS rev: 5'-CAAAAAACCCAAACTCAC AAACTCC-3';

GPX1 BS for: 5'-AGTTTTTGGAAGGGTAATT TGGAT-3'.

Loss of heterozygosity. PCR was carried out for 28 cycles, comprising $30 \mathrm{~s}$ denaturation at $94{ }^{\circ} \mathrm{C}, 30 \mathrm{~s}$ an- nealing at $68{ }^{\circ} \mathrm{C}$ for $G P X 1$ and $63{ }^{\circ} \mathrm{C}$ for $G P X 3$, and 1 min extension at $72{ }^{\circ} \mathrm{C}$. The cycling started by $2 \mathrm{~min}$ denaturation at $94{ }^{\circ} \mathrm{C}$. One of the primers was labeled by Cy5 («IBA», USA):

GPX1 for: 5'-Cy5GAAAACTGCCTCTGCCACGT G ACC-3';

GPX1 rev: 5'-CGAGAAGGCATACACCGACTGG GC-3';

GPX3 for: 5'-Cy5GATGTGAAGCCACTTCGT C-3'; GPX3 rev: 5'-ATG GTG CTG GCC TGT CTA T-3'.

Denaturing PAAG electrophoresis was used to determine the exact size of trinucleotide repeats. The electrophoresis was conducted on automatic laser sequencing machine «ALF express» («Pharmacia Biotech», USA). The mixture, containing $3 \mu \mathrm{l}$ of amplification product and $2 \mathrm{ml}$ of loading buffer $(0.01 \%$ bromphenol blue, $0.01 \%$ xylene cyanol, $98 \%$ formamide), was denatured at $95{ }^{\circ} \mathrm{C}$ for $5 \mathrm{~min}$ before electrophoresis.

Statistical analysis. The nonparametric Wilcoxon test was used to compare mRNA expression of target and reference genes for the same sample. Then groups of samples were compared in respect to the average level of mRNA decrease (LDav) and the frequency of decrease (FD). The LD was calculated as $1 / R$, where $R$ is an mRNA copy number ratio (R) of a target gene versus reference gene and reflects the $n$-fold factor by which the mRNA content decreased in the tumor compared to normal tissue [10]. The nonparametric Kruskal - Wallis and Mann - Whitney rank-sum tests were used to test mRNA differences (both LDav and FD) for each target gene, in tumors with and without metastases. The nonparametric Spearmen's criterion was used to calculate the coefficient of correlation between the LDav for each set of pairs of target genes. P-values $<0.05$ were considered statistically significant. All statistical procedures were performed, using the BioStat software.

Results and discussion. Microarray and SAGE data analysis. To identify putative markers of ccRCC as targets for novel therapeutic drugs, we have investigated genome-wide expression profiles of all human genes in ccRCCs, using a bioinformatics analysis of cDNA microarray data. The results of 11 independent cases of analysis (such as GSE11985, GSE12114, GSE781, GSE12630 and others) were compared with the data reported for 84 normal and 83 tumor samples. In order to find genes with different expression level during kid- 


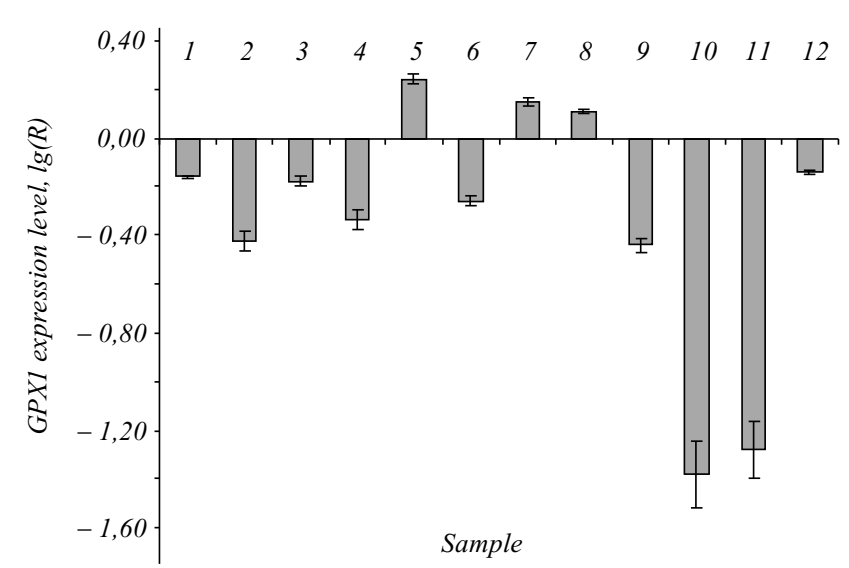

Fig. 1. Relative expression of $G P X 1(n=12)$ in ccRCC: samples $1-6-$ 1-2 stages; 7-12-3-4 stages

ney carcinogenesis, we have also compared the kidney tumor library with 2 libraries of normal tissues, using the SAGE Digital Gene Expression Displayer (DGED). Bioinformatic analysis showed that the TBP gene may be used as a reference gene to investigate the gene expression pattern in human renal cell carcinomas, verifying the results that were published earlier [11].

The 12 genes, that followed a pattern reported in Microarray and SAGE databases, were found. 2 genes $G P X 1$ and GPX3 were chosen to study genetic and epigenetic changes, due to their function in progression and metastasing of renal tumor. Our data supported the hypothesis that these 2 genes are involved in tumorigenesis of ccRCC, due to the fact, that GPX1 and GPX3 expression was simultaneously decreased in renal cell carcinomas, according to microarray and SAGE analysis.

Levels of relative gene expression. The GPX1 expression decreased significantly (from 2 to 94 fold) at the mRNA level (LD) in $87 \%$ of RCC samples ( 8 of 12 , $\mathrm{P}<0.002)$ in comparison with surrounding normal tissue (Fig. 1), according to Q-PCR data. While no significant association was found between gene expression level and gender or age, it should be pointed out that $G P X 1$ expression has a trend to correlate with the histological grade.

The GPX3 expression was down-regulated in all of 12 ccRCC samples in comparison with surrounding normal tissue (Fig. 2). Also no significant association was found between gene expression level and gender or age.

The obtained data on relative expression of GPXI and $G P X 3$ confirm the results of microarray and SAGE analysis.

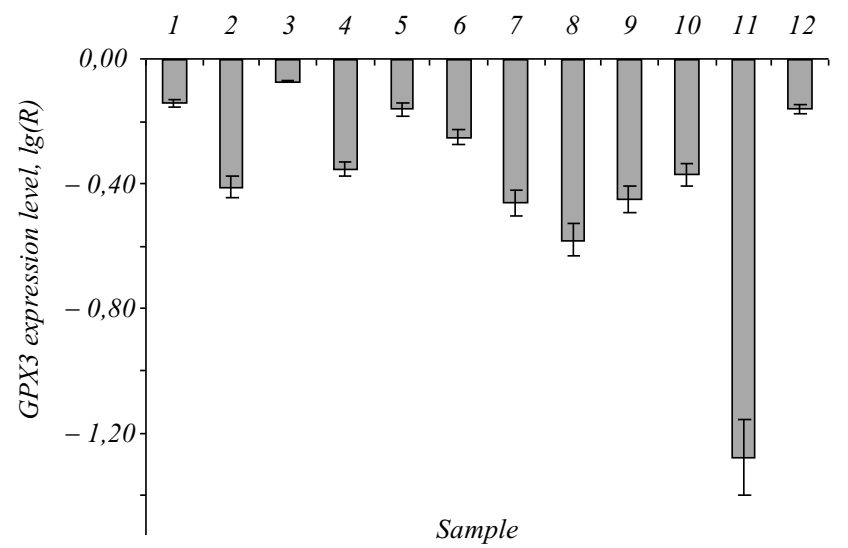

Fig. 2. Relative expression of GPX3 $(n=12)$ in ccRCC: samples $1-6-$ 1-2 stages; 7-12-3-4 stages

To reveal possible mechanisms of gene expression decline, the methylation status of gene promoters was investigated, because it might be an epigenetic inactivation of these genes. It might be and/or a loss of heterozygosity as well.

Analysis of methylation status. To understand the mechanisms, underlying the observed down-regulation of GPXs in renal cancer samples, an analysis of promoter methylation was performed. $\mathrm{CpG}$ islands were identified in the exon1/intron1 region of GPX3. However, no $\mathrm{CpG}$ islands were identified in the promoter region up to 3,000 bp of GPX3. Methylation-specific PCR for $G P X 1$ and $G P X 3$ was performed for 13 ccRCC samples and surrounding normal tissues. No methylation was found in any of renal cancer samples. Bisulfite sequencing was performed on 3 samples (2, 9, and 11) from renal cancer and 3 normal tissues. The results of methylation-specific PCR confirmed the absence of changes in methylation profile, indicating that other mechanism of inhibition of gene expression should be responsible, for example, genetic changes.

Loss of heterozygosity study. The loss of heterozygosity (LOH) method was used for a search for deletion. However, no LOH was found for the GPXI and $G P X 3$ genes.

Trinucleotide repeats determining. The allele's analysis was performed to investigate the trinucleotide polymorphic locus in GPX1 gene in the 13 patients with ccRCC. The cancer-associated allele with five Ala repeats was found in $61.5 \%$ samples of renal cancer. Alleles 6 and 7 constituted a proportion of 27 and $11.5 \%$ respectively. The results are presented in Fig. 3 and Table. 


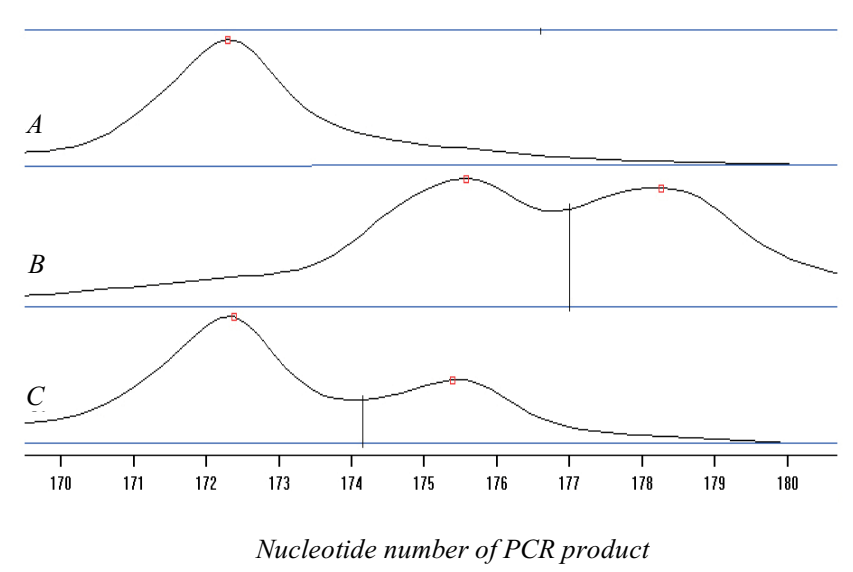

Fig. 3. Example of denaturing PAAG electrophoresis for GPX1 trinucleotide polymorphic locus in renal clear cell carcinoma: $A$ - Ala5 (homozygote); $B$ - Ala6/Ala7; $C$ - Ala5/Ala6 (heterozygotes)

Glutathione peroxidase functions in the detoxification of hydrogen peroxide, and it is one of the most important antioxidant enzymes in humans. Consequently, glutathione peroxidases might have dual role in the regulation of hydroperoxide levels. GPXs are down-regulated in different tumors, such as breast, gastric, and colorectal cancers [13, 14], prostate cancer [15], thyroid cancer of different origin [16, 17], and endometrial carcinoma [18]. Since GPX3 was always highly expres sed in the corresponding healthy tissues, it has been suggested to exhibit tumor suppressor activity. Its main role would be a prevention of cancer initiation, caused by ROS-mediated DNA damage. Glutathione peroxidases play a critical role in detoxifying reactive oxidative species and maintaining the genetic integrity of mammalian cells. Cancer cells produce high amounts of reactive oxygen species (ROS) and evade apoptosis. Hydroperoxides support proliferation, invasion, migration and angiogenesis, but at higher levels they can induce apoptosis, thus being pro- and anti-carcinogenic at the same time. Metastasizing and also apoptosis are inhibited by all GPXs. GPXs that mediated through regulation of other protein activities, may be important for early stages of inflammation-mediated carcinogenesis [19].

A transcription of $G P X 1$ is also regulated by oxygen tension. Specifically, the human GPXI gene has two oxygen response elements (OREs), which under normoxic conditions are important for transcription [20]. Further, it has been proposed that hypoxia-induced suppression of GPX1 transcription may contribute to reperfusion injury after low oxygen tension in cardiomyocytes [21].
Genotype analysis of the human GPX-1 polyalanine polymorphism in ccRCC samples

\begin{tabular}{cc}
\hline$G P X 1$ (N of Ala repeats) & Renal cancer $(n=13)$ \\
\hline $5 / 5$ & 1 \\
$6 / 6$ & - \\
$7 / 7$ & $38.5 \%$ \\
Homozygosity & 5 \\
$5 / 6$ & 3 \\
$5 / 7$ & - \\
$6 / 7$ & $61.5 \%$ \\
Heterozygosity &
\end{tabular}

Interestingly, hyperoxia enhances $G P X 1$ transcription in human umbilicalvein endothelial cells through a mechanism independent of the ORE [22], suggesting that GPXI transcription may be regulated in response to oxygen tension by more than one mechanism.

Analysis of the novel GPX3 promoter identified the Sp-1- and hypoxia-inducible factor-1A (HIF1A) binding sites, as well as the redox-sensitive metal response element and antioxidant response element. HIF1A, activated by hypoxia, was identified as a strong transcriptional regulator of GPX3 expression, leading to almost 3 -fold increase in the expression levels after $24 \mathrm{~h}$ of hypoxia compared with normoxic conditions [23].

It was reported that promoter methylation of GPXs family genes, namely GPX4 and GPX2, was the main mechanism of expression loss in breast cancer [24]. In our research, the methylation of promoter region was not found. Therefore, the decline of expression, probably, could be conditioned by protein interactions. It is known that the oxygen response element sequences bind a nuclear complex that includes the nuclear factor, $\mathrm{Ku}$ [25]. So, GPXs expression is very sensible to the amount of oxygen in a cell. As the innidiation and hypoxic effects in the cell are closely bound, the expression level of GPX1 and GPX3 allows a judgement about a possible innidiation. As was shown before, GPX1 gene is characterized by polyalanine sequence polymorphism in the N-terminal region, which includes three alleles with five, six or seven alanine (Ala) repeats. As was reported in [26], this locus is polymorphic and the allele with five Ala repeats is associated with breast cancer risk. The results of our research confirmed predominance of cancer-associated allele in ccRCC samples. 
Conclusions. The results of our study confirm the data of microarray and SAGE analysis for the GPX1 and $G P X 3$ genes. In the present work we have shown the essential decrease in the relative expression level of GPXI and $G P X 3$ in ccRCC.

Establishment of possible genetic and epigenetic mechanisms that contribute to the expression decline has shown that promoter methylation was not a key mechanism. It was shown that the rarest allele trinucleotide polymorphism was the allele with 7 Ala repeats for the GPX1. The identification of differentially expressed genes in clear-cell renal cell carcinoma would lead to the identification of potential markers that will be of significant value for diagnosis, prognosis, and treatment.

Acknowledgements. This work was partially supported by a project «Identification of molecular genetic markers for diagnostics of malignant neoplasms of epithelial origin», state registration N $0110 \mathrm{U} 004744$.

С. С. Руденко, Г. В. Геращченко, Ю. В. Лапська,

О. О. Богатирьова, С. О. Возіанов, Ю. М. Згонник, В. І. Кашуба

Генетичні та епігенетичні зміни в експресії генів GPX1 і GPX3 за світлоклітинної карциноми нирки людини

Резюме

Мета. Знайти можливі діагностичні і прогностичні маркери каниерогенезу. Методи. Аналіз даних SAGE і мікрочіпів, кількісна ПЛР (Q-PCR), бісульфітне секвенування, метилспецифічна ПЛР. Результати. Біоінформатичним аналізом баз даних $S A G E$ і мікрочіпів виявлено, щуо гени, які кодують глутатіонпероксидазу 1 i 3 (GPX1 i GPX3), мають низький рівень експресії у тканинах раку нирок. Дані Q-PCR щзодо відносної експресії генів GPX1 i GPX3 підтвердили, щуо зазначені гени часто інактивовані у світлоклітинній каричиномі нирки (ccRCC). Кореляції між рівнем експресії $і$ метилюванням промотору у жодному разі не знайдено. Проте встановлено, шео алель з п'ятьма ALA-повторами в $N$-кінцевій ділянці $G P X I$ $\epsilon$ найчастіше повторюваним поліморфним варіантом у паиієнтів з ссRCC. Висновки. Наші дані підтверджують гіпотезу, щчо гени GPX1 i GPX3 залучені до процесу каниерогенезу сcRCC $i$ можуть бути кандидатами на роль генів - супресорів пухлин (TSGs, tumor suppressor genes) при раку нирок.

Ключові слова: карчинома нирки, генетична та епігенетична регуляція, хромосома 3 , кількісна ПЛР у реальному часі, рівень метилювання.

Е. Е. Руденко, А. В. Геращченко, Ю. В. Лапская, О. А. Богатырева, С. А. Возианов, Ю. М. Згонник, В. И. Кашуба

Генетические и эпигенетические изменения в экспрессии генов $G P X 1$ и $G P X 3$ при светлоклеточной карциноме почки человека

Резюме

Цель. Найти предполагаемые диагностические и прогностические маркеры каниерогенеза. Методы. Анализ данных SAGE и мик- рочипов, количественная ПЦР (Q-PCR), бисульфитное секвенирование, метилспецифическая ПЦР. Результаты. Биоинформатическим анализом баз данных $S A G E$ и микрочипов выявлено, что гены, кодируюшие глютатионпероксидазу 1 и 3 (GPX1 и GPX3), имеют низкий уровень экспрессии в тканях рака почек. Данные QPCR по относительной экспрессии генов GPX1 и GPX3 подтвердили, что эти гень часто инактивированы в светлоклеточной карциноме почки (ccRCC). Корреляции между уровнем экспрессии и метилированием промотора ни в одном случае не найдено. Однако обнаружено, что аллель с пятью ALA-повторами в $N$-концевом участке GPX1 является наиболее часто повторяемым полиморфным вариантом у пациентов с сcRCC. Выводы. Наши результаты подтверждают гипотезу, что гены GPX1 и GPX3 вовлечень в прочесс каниерогенеза ccRCC и могут быть кандидатами на роль генов - супрессоров опухолей (TSGs, tumor suppressor genеs) при раке почек.

Ключевые слова: каричнома почки, генетическая и эпигенетическая регуляция, хромосома 3, количественная ПЦР в реальном времени, уровень метилирования.

\section{REFERENCES}

1. Jemal A., Bray F., Center M. M., Ferlay J., Ward E., Forman D. Global cancer statistics // CA Cancer J. Clin.-2011.-61, N 2.P. 69-90.

2. Cheville J. C., Lohse C. M., Zincke H., Weaver A. L., Blute M. L. Comparisons of outcome and prognostic features among histologic subtypes of renal cell carcinoma // Am. J. Surg. Pathol.2003.-27, N 5.-P. 612-624.

3. Awakura Y., Nakamura E., Takahashi T., Kotani H., Mikami Y., Kadowaki T., Myoumoto A., Akiyama H., Ito N., Kamoto T., Manabe T., Nobumasa H., Tsujimoto G., Ogawa O. Microarray-ba sed identification of CUB-domain containing protein 1 as a potential prognostic marker in conventional renal cell carcinoma // J. Cancer Res. Clin. Oncol.-2008.-134, N 12.-P. 1363-1369.

4. Gordiyuk V. V., Kondratov A. G., Gerashchenko G. V., Kashuba $V$. I. Novel epigenetic markers of early epithelial tumor growth and prognosis // Biopolym. Cell.-2013.-29, N 3.-P. 215-220.

5. Berger A. H., Knudson A. G., Pandolfi P. P. A continuum model for tumour suppression // Nature.-2011.-476, N 7359.P. 163-169.

6. Rew D. A. DNA microarray technology in cancer research // Eur. J. Surg. Oncol.-2001.-27, N 5.-P. 504-508.

7. Motamed N., Karimizadeh E. Serial analysis of gene expression and its applications // Genetics in the 3rd millennium.-2010.-8, N 2.-P. 2037-2042.

8. Reiner A., Yekutieli D., Benjamini Y. Identifying diferentially expressed genes using false discovery rate controlling procedures // Bioinformatics.-2003.-19, N 3.-P. 368-375.

9. Speissel B., Beahrs O. H., Hermanek P., Hutter R. V. P., Scheibe $O$. TNM atlas: illustrated guide to the TNM/pTNM classification of malignant tumours.-Berlin; New York: Springer, 1989.$343 \mathrm{p}$.

10. Travis W. D., Coby T. V., Corrin B., Shimosato Y., Brambilla E. World Health Organization International Histological Classification of Tumours; Histological typing of lung and pleural tumours.-Berlin: Springer, 1999.-156 p.

11. Jung M., Ramankulov A., Roigas J., Johannsen M., Ringsdorf $M$., Kristiansen G., Jung K. In search of suitable reference genes for gene expression studies of human renal cell carcinoma by real-time PCR // BMC Mol. Biol.-2007.-8.-P. 47. 
12. Pfaffl $M$. W. A new mathematical model for relative quantification in real-time RT-PCR // Nucleic Acids Res.-2001.-29, N 9.- - 45

13. Gerashchenko G. V., Bogatyrova O. O., Rudenko E. E., Kondratov A. G., Gordiyuk V. V., Zgonnyk Y. M., Vozianov O. F., Pavlova T. V., Zabarovsky E. R., Rynditch A. V., Kashuba V.I. Genetic and epigenetic changes of NKIRAS1 gene in human renal cell carcinomas // Exp. Oncol.-2010.-32, N 2.-P. 71-75.

14. Murawaki Y., Tsuchiya H., Kanbe T., Harada K., Yashima K., Nozaka K., Tanida O., Kohno M., Mukoyama T., Nishimuki E., Kojo H., Matsura T., Takahashi K., Osaki M., Ito H., Yodoi J., Murawaki Y., Shiota G. Aberrant expression of selenoproteins in the progression of colorectal cancer // Cancer Lett.-2008.-259, N 2.-P. 218-230

15. Pawlowicz Z., Zachara B. A, Trafikowska U., Maciag A., Marchaluk E., Nowicki A. Blood selenium concentrations and glutathione peroxidase activities in patients with breast cancer and with advanced gastrointestinal cancer // J. Trace Elem. Electrolytes Health Dis.-1991.-5, N 4.-P. 275-277.

16. Yи Y. P., Yu G., Tseng G., Cieply K., Nelson J., Defrances M., Zarnegar R., Michalopoulos G., Luo J. H. Glutathione peroxidase 3, deleted or methylated in prostate cancer, suppresses prostate cancer growth and metastasis // Cancer Res.-2007.-67, N 7.-P. 8043-8050.

17. Schmutzler C., Mentrup B., Schomburg L., Hoang-Vu C., Her$\operatorname{zog} V$., Kohrle J. Selenoproteins of the thyroid gland: expression, localization and possible function of glutathione peroxidase 3 // Biol. Chem.-2007.-388, N 10.-P. 1053-1059.

18. Hasegawa Y., Takano T., Miyauchi A., Matsuzuka F., Yoshida H. Y., Kuma K., Amino N. Decreased expression of glutathione peroxidase mRNA in thyroid anaplastic carcinoma // Cancer Lett.2002.-182, N 1.-P. 69-74.
19. Karlsson S., Klinga-Levan K. Expression analysis of human endometrial adenocarcinoma in an inbred rat model // Adv. Exp. Med. Biol.-2008.-617.-P. 503-509.

20. Brigelius-Flohe R., Kipp A. Glutathione peroxidases in different stages of carcinogenesis // Biochim. Biophys. Acta.-2009.1790, N 11.-P. 1555-1568.

21. Cowan D. B., Weisel R. D., Williams W. G., Mickle D. A. Identification of oxygen responsive elements in the 5'-flanking region of the human glutathione peroxidase gene // J. Biol. Chem.1993.-268, N 36.-P. 26904-26910.

22. Merante F., Altamentova S. M., Mickle D. A., Weisel R. D., Thatcher B. J., Martin B. M., Marshall J. G., Tumiati L. C., Cowan D. B., Li R. K. The characterization and purification of a human transcription factor modulating the glutathione peroxidase gene in response to oxygen tension // Mol. Cell Biochem.-2002.229, N 1-2.-P. 73-83.

23. Jornot L., Junod A. F. Hyperoxia, unlike phorbol ester, induces glutathione peroxidase through a protein kinase $\mathrm{C}$-independent mechanism // Biochem. J.-1997.-326, Pt 1.-P. 117-123.

24. Bierl C., Voetsch B., Jin R. C., Handy D. E., Loscalzo J. Determinants of human plasma glutathione peroxidase (GPx-3) expression // J. Biol. Chem.-2004.-279, N 26.-P. 26839-26845.

25. Kulak M. V., Cyr A. R., Woodfield G. W., Bogachek M., Spanheimer P. M., Li T., Price D. H., Domann F. E., Weigel R. J. Transcriptional regulation of the GPX1 gene by TFAP2C and aberrant CpG methylation in human breast cancer // Oncogene.-2013.32, N 34.-P. 4043-51.

26. Hu Y. J., Diamond A. M. Role of glutathione peroxidase 1 in breast cancer: loss of heterozygosity and allelic differences in the response to selenium // Cancer Res.-2003.-63, N 12.-P. 33473351 . 